\title{
DEVELOPMENT OF NON-BANKING SECTOR IN EU AND BULGARIA
}

\author{
M. Nedelchev* \\ International Business School, Sofia, Bulgaria
}

\begin{abstract}
The Article explores the development of non-banking sector in the EU. The new institutional framework sets a new role for the financial intermediaries outside commercial banks. The analysis reveals macroeconomic issues which define the modern expectations to microeconomic players. The trend in Bulgaria follows dynamic processes in the EU. In addition to European issues, Bulgarian ones include socio-demographic red tapes for non-banking sector.
\end{abstract}

Key words: insurance corporations, pension funds

\section{INTRODUCTION}

The development of society and economy traditionally linked to the role of financial intermediaries. In the economic history of the non-banking sector expectations are not new. The sector of financial intermediation periodically extends to non-bank financial intermediaries through new financial services that are used to expand lending (1). As an entrepreneur, non-bank financial intermediaries undertake risk for innovative activities which at a later stage are performed by banking sector.

In international practice, there is a wide variety of definitions and laws for the non-banking sector, which further hampers the collection and processing of data in studies (2). The classification of the G20 considers the financial sector into three groups: banks; securities dealers and financial derivatives; nonbank financial intermediaries (3). The latter concerns insurance companies, pension funds and hedge funds. Given the expansion of credit activity of insurance companies and pension funds, since 2014 the Financial Stability Board studies and analyzes the non-banking sector.

In EU the financial sector includes three groups of financial intermediaries: credit institutions; insurance companies and pension funds; other financial intermediaries

${ }^{*}$ Correspondence to: Miroslav Nedelchev, International Business School, 138 V. Levski Blvd., 1000 Sofia, Bulgaria, +359 889199 269,nedelchev.miroslav@acad.ibsedu.bg (investment funds, special purpose entity, securities and derivatives dealers). In Bulgaria the financial sector includes banking system; insurance companies; companies, specializing in lending; leasing companies; limited special purpose entity; nonbank investment intermediaries; local investment funds; funds for supplementary pension insurance (4).

\section{MATERIALS}

The leading role in lending to the real sector in the EU historically has played by the banking sector. This tradition defines the magnitude of the banking sector and the development of non-banking sector. With the expansion of services provided by the non-banking sector, including credit intermediation, measures to support financial system stability marked a transition from a "culture of subsidy“ to "finance economy" (5). Unlike the model of banks to „know your customer", the non-bank intermediaries used as a management tool the model „life cycle of the customer" and adapt their services to the temporal dynamics of the client.

The transformations in the EU to strengthen the financial system determine particular attention to alternative sources of funding (6). The weak growth in bank lending requires a balanced approach and new financial mix. The approach sets benefits for certain jurisdictions, but also led to new sources of systemic risk. The sustainability of non-banking financial sector should be seen in the context of the overall stability of the EU financial system.

The changes in the financial system are aimed at dynamics in the structure of financial 
intermediaries themselves. Their effects are increasing importance of other financial intermediaries - insurance companies and pension funds.

\section{DISCUSSION}

\section{Non-banking sector in the $E U$}

The imbalance in the financial sector is offset by the rebalancing:

- Increased lending by non-bank intermediaries at the expense of banks. At the end of 2013 the global sector of insurance companies and pension funds constitute $18 \%$ of the total assets of the financial system as their assets reached 54.8 trillion USD.

- Increasing the role of pension funds to insurance companies. The non-banking sector is dominated by insurance companies that hold about $80 \%$ of the total assets of the sector (7). Despite the large share of the insurance companies, by 2009 the pension funds sector has greater growth of insurance companies - an average annual growth reached $8 \%$ in pension funds and $6 \%$ for insurance companies. This trend was first introduced in 1999 to increase the provision of pension funds, reflecting the demographic trends and the perceived need to create complementary pension schemes.

The new expectations to the non-banking sector changing the priorities of roles:

- The primary role of the non-banking sector is performing his social functions. Financial commitments to customers are leaders in expectations. Achieving high profits in the short term be transformed into long-term investments with moderate risk. The basis of this role is the change in the demographic and social situation in the EU.

- The secondary role is financing the real sector. Historical expectations are mainly economic - lending and servicing the real sector that is associated with taking high risk. New expectations are oriented mainly at social functions, while economic functions remain a priority for the banking sector.

The pension funds switch to the new conditions for their role in the society and the economy:

- The trend towards increasing age of the population is a matter of solving not only for the EU. Pension funds should adapt their financial flows to provide the means to fulfill their financial obligations towards insured persons.

- With the elimination of restrictions on labor mobility of human capital a new question arises - the degree of accessibility to the pension system of another member state. The harmonization of the internal market for pension services provides to implement a common European ,personal pension plan“. The plan poses challenges to protect pension schemes and to meet future obligations of pension funds. The development of harmonized measures will help to promote the portability of social rights, which will lead to the mobility of human capital in the EU (8).

- Using cross-border schemes for retirement is limited due to different tax and social laws and regulatory systems. Despite the progress in the integration, harmonization of conditions for retirement remains in the national borders and development of pension funds is with limited opportunities for conducting cross-border activities. The Directive 2003/41/EC on the activities and supervision of institutions for occupational retirement provision provides for a minimum harmonization of pension funds and to allow Member States a considerable degree of freedom to create rules at national level. The Directive provides further incentives due to an aging population to move from PAYG systems have little resistance to provisioning for retirement.

- Stability in the financial system. As part of the financial system, to the non-banking sector should be carry out supervision and regulation because of the probability of systemic risk. Unlike the banking sector, in the non-banking sector should apply an approach similar to the traditional reduction of systemic crises. In the non-banking sector macroeconomic problems and microeconomic issues (individual financial institution is ,too big") are not identical. Monitoring by the competent authority is aimed at reaching the optimum size of the non-banking intermediary relative to the European market - a big intermediary, to be able to operate cross-border and to diversify risk, but small to be resolved by EU resources.

- Unlike the banking sector, in the nonbanking sector it is possible to achieve a balance between financial stability and economic efficiency. Modern expectations of pension funds are pension services at affordable prices, combined with the flexibility of the labor market as part of the conditions of employment (9). In this sense, the sustainability of the pension system should be considered together with the stability of the European financial system, combined with increasing age.

The other non-bank intermediary, insurance companies, besides changes in the demographic situation, the additional points are related to: 
- Improvement of the middle class. Unlike Western Europe, in Eastern Europe the insurance culture, especially life insurance, there is no historical root. In most cases, the citizens have an insurance that is most often due to a requirement of the lending bank for insurance of real property or on the initiative of the employer for life insurance due to law requirement or tax preferences.

- Low market growth, which has resulted in increased competitive pressure. Due to the low GDP growth in the Eastern Europe, the growth in demand for insurance products is expected to be moderate.

Insurance companies switch to the new conditions for their role in society and the economy:

- Stability of the financial system. Insurance companies involved in the transfer of liquidity (i.e. through liquidity swap arrangements with other financial intermediaries) and credit risk (i.e. in the form of mortgage insurance) (10).

- Directive „Solvency II“ for harmonization of regulatory practices introduced the standard ,prudent principal“. It requires companies to invest only in assets and instruments whose risks are reliably defined, measured, managed, controlled and accounted for, and invest in a way that ensures reliability, quality, liquidity and profitability of the portfolio.

- Future importance of insurance companies in their role of ,patient investor“. Lending to emerging companies is critical to the economy will lead to an effective division of labor within the financial system. To fulfill this role actively, insurance companies must be in a position to invest in a broad class of financial assets.

- Insurance companies conduct process of diversification of its activities. The process is characterized by diversification of services in life insurance and healthcare, unlike banks diversify their activities in other countries.

\section{Non-banking sector in Bulgaria}

The non-banking sector in Bulgaria emerged in the 1990s. The elimination of state monopoly led to the registration of financial companies with local capital. Unlike the banking sector, the non-banking sector started its activities in improved regulatory and institutional framework.

The integration of non-banking sector in Bulgaria began in 2004 with the implementation of European Directives. The acquisitions of the EU and the creation of a special authority to regulation improve confidence in the non-banking sector. A good regulatory framework and a stable macroeconomic environment presented the domestic market as significant to foreign investors from the EU and in most - the insurance sector. The increased competition after a series of foreign acquisitions results to diversify and improve services.

The non-banking sector in Bulgaria follows the trends in the EU. In addition to the difficulties inherent in other countries, the non-banking sector in Bulgaria is distinguished by specifics arising from carried out reforms and due to the effects of global economic crisis. The low GDP growth slows demand for services of non-bank intermediaries, mainly in the insurance sector. Tight market has resulted in increased competition and taking excessive risk. The introduced system of free providing of services through a single license failed to fully integrate the Bulgarian market and it continues to develop as a secondary lender. The low level of transparency of financial performance, as well as protecting the interests of customers remain major factors for the weak interest in the non-banking services. The reduced performance against competitors from other Member States can be taken as a signal to inefficient management of quasi equity.

The prospects for the development of nonbanking sector in Bulgaria include restructuring the supervisory framework. By analogy with the practice of the EU, the approach for monitoring of two supervisors for banking and non-banking sector should be replaced by a new consolidated authority with greater powers. The cooperation and exchange of information with competent authorities of other countries will ensure the stability of the financial sector and protect the interests of customers. The participation in the newly dedicated supervisory institutions of the EU will modernize the national sector through implementation of international best practices.

\section{CONCLUSION}

The development of non-banking sector removes the distortions created by national borders. The expansion of the participants for crediting the real sector to the non-banking sector has catalytic effect on the banking sector in the valuation of assets, provisioning and increasing of capital. In turn, the deleveraging of the banking sector will stimulate the development of non-banking sector.

The differences in economic performance in the EU put the risk of market fragmentation with the influence of business models between insurance companies with cross-border 
operation and pension funds with national activities. Regardless of uniting in a group of non-banking sector, the opportunities for intervention on pension funds are significantly larger compared with insurance companies. Common to both actions, pensions and insurance, is social-demographic situation in which social costs have an impact on the public budget. The challenge is finding a balance between the justification of social expectations, the exercise of economic roles, preserve financial stability and enhance the competitiveness of the single market. To achieve this balance is needed transnational policy for coordination.

\section{REFERENCES}

1. Thorn, R. Nonbank Financial Intermediaries Credit Expansion and Monetary Policy. IMF Staff Papers, 1958.

2. Financial Stability Board. Global Shadow Banking. Monitoring Report, 2014.

3. Financial Stability Board. Proposed regulatory framework for haircuts on securities financing transactions. 2013.
4. Българска Народна Банка. Банките в България. Април - юни 2014 г.

5. Financial Stability Board. Global Shadow Banking. Monitoring Report, 2014.

6. Хубенова, Т. Съвременните концепции за икономическия растеж и модернизацията в световната икономика: предизвикателствата пред ЕC и алтернативи за България, В Сборник с доклади от Международна конференция „Икономически растеж: стимули и ограничители“, ИИИ на БАН, 0607.10.2014 г.

7. European Central Bank. Monthly Bulletin. ECB, January, 2012.

8. Marty, O. Capital-Markets Union: tentative shape and priorities. Fondation Robert Schuman, European Issues, № 335, 2014.

9. Borsjé, P., H. Meerten. A European Pensions Union. National Bank of Slovakia, Series 2014, May, 5, 22.

10.Deutsche Bundesbank. Monthly Report. March, 2014. 